\title{
Smoke compounds aggravate stress inflicted on Brassica seedlings by unfavourable soil conditions
}

\author{
R. BĄCZEK-KWINTA*,+, J. ANTONKIEWICZ ${ }^{* *}$, A. ŁOPATA-STASIAK*, and W. KĘPKA** \\ Department of Plant Physiology, Faculty of Agriculture and Economics, University of Agriculture in Kraków, \\ 30-239 Kraków, Podtużna 3, Poland* \\ Department of Agricultural and Environmental Chemistry, University of Agriculture in Krakow, 31-120 Kraków, \\ Mickiewicza 21, Poland ${ }^{* *}$
}

\begin{abstract}
The aim of the study was to assess the physiological status of Brassica seedlings grown in two types of soils following a single application of smoke water (SW). One soil was contaminated with heavy metals from a local smelter, and another was sandy and poor in nutrients. Three-week monitoring indicated that soil composition was the primary factor affecting chlorophyll fluorescence $(\mathrm{CF})$ parameters, growth, and development of seedlings, and the contaminants affected the plants more than the lack of nutrients. SW aggravated the negative impact of heavy metals, which became visible when the plants transiently suffered from the heavy metal exposure. Most of CF parameters changed suddenly but then the trend reversed indicating that plants gradually adapted to the specific conditions. However, this was not reflected in the final biomass of the seedlings. This might be due to redirection of photosynthates towards protective mechanisms against toxic effects of metals.
\end{abstract}

Additional key words: greenness index; karrikin; soil contamination; soil pollution; swailing.

\section{Introduction}

Crop plants are always forced to cope with more than one stress factor. Soil can be a source of several stressors at the same time, whether it is too acidic, poor in nutrients, or contaminated with heavy metals. Grass burning (swailing), which is common but illegal in the Central Europe, brings another threat to the agricultural ecosystem (Cosgrove 2014, Bączek-Kwinta et al. 2017). Smoke is an aerosol naturally dispersed and diluted but its rapid deposition in the soil after rainfall may trigger changes in plant communities. Native Australians or Africans used smoke to improve crop quality. Nowadays, attempts are also made to increase crop productivity with an aqueous smoke formulation (smoke water, SW) (Kulkarni et al. 2008, 2011). Smoke water may also emulate the mode of action of swailing-derived smoke on plants (BaczekKwinta et al. 2017). However, the effects of smoke are complex and depend on the concentration of active substances, namely karrikins and trimethylbutenolide (Flematti 2013, Kochanek et al. 2016, Pošta et al. 2013, 2017). Plants show different sensitivity to smoke (Reyes and Trabaud 2009, Dayamba et al. 2010, Long et al. 2011, Bączek-Kwinta et al. 2017).

Plant fitness can be assessed based on the parameters of the fluorescence of chlorophyll $a$ (CF). Different systems of point data measurements and CF imaging help to evaluate the effects various factors exert on the photosynthetic apparatus and yield (Baczek-Kwinta et al. 2011a, Murchie and Lawson 2013, Borek et al. 2016). $\mathrm{F}_{\mathrm{v}} /$ $\mathrm{F}_{\mathrm{m}}$, the maximal quantum yield of PSII photochemistry, indicating direct damage to PSII reaction centres, is one of the most commonly used parameters (Baker et al. 2008, Bączek-Kwinta et al. 2011b, Murchie and Lawson 2013). Another popular one is the effective quantum efficiency of $\operatorname{PSII}\left(\Phi_{\mathrm{PSI}}\right)$, which correlates with $\mathrm{CO}_{2}$-uptake rate in leaves and is directly associated with carbon assimilation (Kalaji et al. 2014). $\Phi_{\text {PSII }}$ often corresponds with the coefficient of photochemical quenching of fluorescence, qp. However, it may negatively correlate with nonphotochemical quenching, $\mathrm{q}_{\mathrm{NP}}$, which reflects dissipation of absorbed light energy that cannot be used in photosynthesis (Maxwell and Johnson 2000, Sofo et al. 2009).

A general purpose of the study was to compare the condition of the photosynthetic apparatus and the biometric parameters of white cabbage grown in the soil poor in nutrients or contaminated with heavy metals, following a single application of SW. Concentration of SW was considered low according to its physiological mode of action (Kulkarni et al. 2008, Zuloaga-Aguilar

Received 13 March 2018, accepted 1 August 2018.

${ }^{+}$Corresponding author; e-mail: rrbaczek@ cyf-kr.edu.pl

Abbreviations: Chl - chlorophyll; DM - dry mass; FM - fresh mass; $\mathrm{F}_{0}$ - minimal fluorescence yield of the dark-adapted state; $\mathrm{F}_{\mathrm{v}} / \mathrm{F}_{\mathrm{m}}$ - maximal quantum yield of PSII photochemistry; $\mathrm{q}_{\mathrm{NP}}$ - nonphotochemical quenching coefficient; $\mathrm{q}_{\mathrm{p}}-$ photochemical quenching coefficient; SD - standard deviation; SW - smoke water; $\Phi_{\text {PSII }}$ - effective quantum yield of PSII photochemistry.

Acknowledgement: The study was supported by the University of Agriculture in Kraków, Research programmes No. DS 3145 and DS 3163. 
et al. 2011). The soils used in the experiment have been used for crop cultivation for years. One of them, called Bukowno, is contaminated with heavy metals due to the location near non-ferrous metal smelter ZGH Bolesław SA (Gruszecka-Kosowska and Kicińska 2017). Brassica oleracea var. capitata and other cabbages are among the most popular vegetables in the world (http://www.fao.org/ faostat/). However, white cabbage is also recommended for cleaning up soils contaminated with metals, as it is capable of accumulating $\mathrm{Cd}$ at a rate of 6-360 $\mathrm{g}(\mathrm{Cd})$ per hectare due to large plant biomass (Baczek-Kwinta et al. 2011b, Kusznierewicz et al. 2012). We wanted to verify if SW could alleviate the status of cabbage seedlings grown in Cd-polluted soils. To check how general the SW effects are, we also applied its aqueous solution to plants grown in poor sandy soil (called Podlesie) collected from the vicinity of the smelter.

\section{Materials and methods}

Plant material: The experiment was conducted in a greenhouse (phytotron) at the University of Agriculture in Kraków, Poland. Seeds of white cabbage cultivar 'Kamienna Głowa' (Brassica oleracea ssp. capitata $f$. alba L.) were dressed with antifungal seed dressing T75/ DS/WS (vendor: Organika-Azot Jaworzno, Poland) (70\% Thiuram), and then sown into pots of $100-\mathrm{cm}^{3}$ volume filled with garden soil. Seedlings grew at a night-day temperature of $5-15 / 15-20^{\circ} \mathrm{C}$ and were transplanted into experimental soils (5-L pots) at the stage of six to eight leaves.

Ten unified seedlings were planted into Bukowno soil taken from the vicinity (approx. $1 \mathrm{~km}$ ) of Mining \& Metallurgy Enterprise ZGH Bolesław SA in Bukowno town, Małopolska region, dealing with zinc and lead ore processing $\left(50^{\circ} 16^{\prime} 20^{\prime \prime} \mathrm{N}, 19^{\circ} 29^{\prime} 6^{\prime \prime} \mathrm{E}\right.$; soil composition in the text table below). Another set of ten unified seedlings was planted in the soil taken from Podlesie $(50.23 \mathrm{~N}, 19.47 \mathrm{E})$, $5 \mathrm{~km}$ away from the aforementioned mining and smelting complex (soil composition in the following text table). Further vegetation was carried out at $20-25^{\circ} \mathrm{C}$ during day and $17-20^{\circ} \mathrm{C}$ at night, and relative humidity of $30-50 \%$. Seven days after transplantation, five seedlings in each soil were watered with the aqueous extract of smoke (SW, $100 \mathrm{~mL}$ ). The extract was prepared by bubbling smoke from burning of $100 \mathrm{~g}$ of dry meadow grass into $300 \mathrm{~mL}$ of distilled water for $2 \mathrm{~h}$, and diluting it with distilled water $1: 1,000(\mathrm{v} / \mathrm{v})$. The control plants were treated with distilled water, and during further growth all seedlings were watered with tap water to maintain proper soil moisture reflected by a lack of wilting and development of new leaves (data not shown).

Soil material and analysis: The soil material was dried in a forced air circulation dryer at $70^{\circ} \mathrm{C}$. After drying and sifting through a $2-\mathrm{mm}$ sieve, soil $\mathrm{pH}$ was determined by a potentiometric method, in $1 \mathrm{~mol}(\mathrm{KCl}) \mathrm{dm}^{-3}$. Organic carbon was evaluated by Tiurin method (Mebius 1960), and total nitrogen content by Kjeldahl method. The contents of available $\mathrm{P}$ and $\mathrm{K}$ were established using Egner method, and of available Mg according to Schachtschabel method (Jones and Case 1990, Ostrowska et al. 1991).

The contents of macroelements (total forms), namely $\mathrm{Ca}, \mathrm{Na}$, and heavy metals (total forms), such as $\mathrm{Fe}, \mathrm{Mn}$, $\mathrm{Zn}, \mathrm{Ni}, \mathrm{Cu}, \mathrm{Cd}, \mathrm{Pb}$, and $\mathrm{Cr}$, were assessed after digesting the soil in a mixture of concentrated acids: $\mathrm{HNO}_{3}(65 \%)$ and $\mathrm{HClO}_{4}(70 \%), 3: 2(\mathrm{v} / \mathrm{v})$. Then the assays with atomic emission spectrometer Perkin Elmer Optima $7300 \mathrm{DV}$ spectrometer ICP-OES were performed (Jones and Case 1990, Ostrowska et al. 1991, Kusznierewicz et al. 2012). Each sample was analyzed in three replicates and data were analyzed using a quantitative analysis mode. Scanning of each sample was also repeated three times to gather repetitive results. During measurements, care was taken to avoid memory effect and therefore a wash-out time of 0.5 min was used (van de Wiel 2003). Accuracy of the analytical methods was verified based on certified reference materials: CRM IAEA/V - 10 Hay (International Atomic Energy Agency), CRM - CD281 - Rey Grass (Institute for Reference Materials and Measurements), CRM023-050 Trace Metals - Sandy Loam 7 (RT Corporation).

Greenness index (relative $\mathrm{Chl}$ content) and the parameters of $\mathbf{C h l} \boldsymbol{a}$ fluorescence (CF): The measurements were taken on $13^{\text {th }}, 21^{\text {th }}$, and $30^{\text {th }}$ day of cultivation and performed on fully developed leaves (third to fifth counting from the top) without any discoloration. The same leaves were used for both assays. Greenness index was measured with a portable Chl meter CL-01 (Hansatech Instruments, UK). Chl $a$ and $b$ are capable of absorbing red light but they do not absorb infrared light. The $C L-01$ measures the absorbance in these areas, and yields numerical values

Chemical composition of soils used in the experiment. Means of five replicates are given $\pm \mathrm{SD}$. DM - dry mass.

\begin{tabular}{|c|c|c|}
\hline \multirow{2}{*}{ Parameter } & \multicolumn{2}{|l|}{ Location (soil) } \\
\hline & Bukowno & Podlesie \\
\hline Texture & Loamy sand & Sandy soil \\
\hline $\mathrm{pH}_{(\mathrm{H} 2 \mathrm{O})}$ & 6.20 & 5.17 \\
\hline $\mathrm{pH}_{(\mathrm{KCl})}$ & 6.00 & 4.98 \\
\hline \multicolumn{3}{|l|}{ Macronutrients } \\
\hline $\mathrm{C}-$ organic $[\%]$ & $1.313 \pm 0.008$ & $0.899 \pm 0.032$ \\
\hline $\mathrm{N}-$ total & $0.104 \pm 0.008$ & $0.062 \pm 0.010$ \\
\hline $\mathrm{P}-$ available $\left[\mathrm{mg} \mathrm{kg}^{-1}(\mathrm{DM})\right]$ & 64.2 & 47.5 \\
\hline $\mathrm{K}$ - available $\left[\mathrm{mg} \mathrm{kg}^{-1}(\mathrm{DM})\right]$ & 70.2 & 20.6 \\
\hline $\mathrm{Mg}$ - available $\left[\mathrm{mg} \mathrm{kg}^{-1}(\mathrm{DM})\right]$ & 45.6 & 29.3 \\
\hline $\mathrm{Ca}\left[\mathrm{mg} \mathrm{kg}^{-1}(\mathrm{DM})\right]$ & $4058 \pm 333$ & $0.00 \pm 20.7$ \\
\hline $\mathrm{Na}\left[\mathrm{mg} \mathrm{kg}^{-1}(\mathrm{DM})\right]$ & $280 \pm 1.67$ & $145 \pm 6.10$ \\
\hline \multicolumn{3}{|l|}{ Heavy metals } \\
\hline $\mathrm{Fe}\left[\mathrm{mg} \mathrm{kg}^{-1}(\mathrm{DM})\right]$ & $5552 \pm 217$ & $3588 \pm 210$ \\
\hline $\mathrm{Mn}\left[\mathrm{mg} \mathrm{kg}^{-1}(\mathrm{DM})\right]$ & $605 \pm 21.0$ & $364 \pm 14.4$ \\
\hline $\mathrm{Zn}\left[\mathrm{mg} \mathrm{kg}^{-1}(\mathrm{DM})\right]$ & $2122 \pm 39.4$ & $319 \pm 4.11$ \\
\hline $\mathrm{Ni}\left[\mathrm{mg} \mathrm{kg}^{-1}(\mathrm{DM})\right]$ & $7.07 \pm 0.32$ & $3.85 \pm 0.28$ \\
\hline $\mathrm{Cu}\left[\mathrm{mg} \mathrm{kg}^{-1}(\mathrm{DM})\right]$ & $6.78 \pm 0.25$ & $4.43 \pm 0.60$ \\
\hline $\mathrm{Cd}\left[\mathrm{mg} \mathrm{kg}^{-1}(\mathrm{DM})\right]$ & $24.4 \pm 0.40$ & $2.63 \pm 1.16$ \\
\hline $\mathrm{Pb}\left[\mathrm{mg} \mathrm{kg}^{-1}(\mathrm{DM})\right]$ & $344 \pm 6.54$ & $123 \pm 6.45$ \\
\hline $\mathrm{Cr}\left[\mathrm{mg} \mathrm{kg}^{-1}(\mathrm{DM})\right]$ & $7.15 \pm 0.26$ & $5.28 \pm 0.43$ \\
\hline
\end{tabular}


proportional to the Chl content (Cassol et al. 2008, Borek et al. 2016).

$\mathrm{CF}$ measurements were taken using a pulse-modulated fluorescence monitor system (FMS-2, Hansatech Instruments, UK). Modulation beam (duration pulses of $1.8 \mu \mathrm{s}, 2.3 \mathrm{kHz}$ ) was provided by amber LED (peak wavelength $594 \mathrm{~nm}$, PFD ca. $0.05 \mu$ mol(photon) $\mathrm{m}^{-2} \mathrm{~s}^{-1}$ ). Actinic and pulse irradiations were provided by a halogen lamp $(20 \mathrm{~W})$. The signal detector was a PIN photodiode with a long-pass filter $(>700 \mathrm{~nm})$, and the sampling rate was $10-20 \mathrm{kHz}$ (depending on the instrument mode). A clip with an optical fibre was fastened to the central part of the attached leaf for $20 \mathrm{~min}$. Then the leaf was irradiated by a saturating light pulse to determine $\mathrm{F}_{\mathrm{m}}$ (intensity of 90 units, duration $0.9 \mathrm{~s}$ ), after which the actinic light [25 units $=1,500 \mu \mathrm{mol}$ (photon) $\left.\mathrm{m}^{-2} \mathrm{~s}^{-1}\right]$ was switched on for $270 \mathrm{~s}$. The photochemical quenching $\left(\mathrm{q}_{\mathrm{P}}\right)$ and quantum yield of electron transport at PSII $\left(\Phi_{\text {PSII }}\right)$ were determined according to Genty et al. (1989) and Schreiber et al. (1986).

Biometric analyses: The length of plant organs and their fresh and dry mass were assessed on $40^{\text {th }}$ day of the experiment. Fresh mass (FM) was recorded immediately after cutting, then the tissues were dried until constant mass $\left(80^{\circ} \mathrm{C}, 24 \mathrm{~h}\right)$, kept over silica gel for $24 \mathrm{~h}$, and weighed again for their dry mass $(\mathrm{DM})(\mathrm{d}=0.001 \mathrm{~g})$.

Statistical analysis: All the measurements were performed in five replicates $(n=5)$. For greenness index and CF parameters, the significance of the soil and the treatment (SW) was evaluated by repeated measurement analysis of variance ( $A N O V A)$. For biometric analyses, two-factor $A N O V A$ was performed. Two means of plants in specific soil and over a specific period were compared with Student's $t$-test, and the differences were considered significant at $P \leq 0.05$. ANOVA analyses were preceded by KolmogorovSmirnov test to confirm normal data distribution. All calculations were carried out using Microsoft Office Excel 2007 and Statistica 12.0 (SPSS Inc., Chicago, IL, USA).

\section{Results}

Characteristics of soils: Based on the framework guide- lines for agriculture (Kabata-Pendias et al. 1995), Bukowno soil was characterized by natural $\left(0^{\circ}\right)$ content of $\mathrm{Cr}, \mathrm{Cu}$, $\mathrm{Ni}$, medium $\left(\mathrm{III}^{\circ}\right) \mathrm{Pb}$ contamination, heavy $\left(\mathrm{IV}^{\circ}\right) \mathrm{Zn}$ contamination, and very heavy $\left(\mathrm{V}^{\circ}\right) \mathrm{Cd}$ contamination (see the text table in Materials and methods). Podlesie soil featured natural $\left(0^{\circ}\right)$ content of $\mathrm{Cr}, \mathrm{Cu}, \mathrm{Ni}$ and medium (III ${ }^{\circ}$ ) contamination with $\mathrm{Cd}, \mathrm{Pb}$ and $\mathrm{Zn}$. The content of organic carbon and total nitrogen was low in both cases and comparable with other soils occurring in Poland (Kabata-Pendias and Mukherjee 2007, Łukowiak et al. 2016). The content of available $\mathrm{Mg}$ and $\mathrm{P}$ in Bukowno soil was moderate and available $\mathrm{K}$ was low, while the content of available $\mathrm{P}, \mathrm{K}$, and $\mathrm{Mg}$ in Podlesie soil was medium, low, and very low, respectively (Ostrowska et al. 1991). Based on fertilization recommendations (Ostrowska et al. 1991), Bukowno soil was slightly acidic and Podlesie soil was acidified. Bukowno soil contained more organic carbon and nitrogen than the Podlesie soil, more biogenic compounds, such as $\mathrm{Na}, \mathrm{Ca}, \mathrm{Mg}$, and $\mathrm{K}$, but also more heavy metals. Its granulometric composition matched loamy sand with $87 \%$ of sand, $12 \%$ of silt, and $1 \%$ of clay fractions (Marcinek and Komisarek 2011). Podlesie soil was poor in nutrients and lacked calcium. It contained $91 \%$ of sand, $8 \%$ of silt, and $1 \%$ of clay, and was classified as sandy (text table).

Greenness index and CF parameters during vegetation: When analyzed globally, the greenness index depended only on the measurement date. On $21^{\text {st }}$ day, its values dropped, but on $30^{\text {rd }}$ day they increased above the initial level (Table 1, Fig. $1 A, B$ ). Changes in $\mathrm{F}_{0}$ depending on the measurement date were visible as a huge drop on the last day of the experiment. The impact of soil on $\mathrm{F}_{0}$ was manifested as lower values for Podlesie than that of Bukowno soil (Table 1, Fig. 1C,D). We noticed no changes in $\mathrm{F}_{\mathrm{v}} / \mathrm{F}_{\mathrm{m}}$ parameter (Table 1, Fig. $1 E, F$ ).

The values of $\Phi_{\text {PSII }}$ and $\mathrm{q}_{\mathrm{P}}$ showed similar trends for both the soil and measurement date. Both parameters were lower in the plants grown in Bukowno soil than in Podlesie soil, and they declined temporarily on $21^{\text {st }}$ day (Table 1 , Fig. 2A-D). Similar drop turned out reversible for $\mathrm{q}_{\mathrm{NP}}$ (Fig. 2E,F, Table 1).

Table 1. Significance of the tested factors (analysis of variance for three measurement dates, repeated measurements) indicating the impact of soil (Bukowno contaminated with heavy metals and Podlesie poor in nutrients and acidic, see the text table in Materials and methods) and treatment with smoke water (SW) on the greenness index and CF parameters of cabbage seedlings. $* * *-\alpha \leq 0.001 ; *-\alpha \leq 0.05$; ns - insignificant. $F_{0}$ - minimal fluorescence yield of the dark-adapted state; $F_{v} / F_{m}$ - maximal quantum yield of PSII photochemistry; $\Phi_{\mathrm{PSII}}$ - effective quantum yield of PSII photochemistry; $\mathrm{q}_{\mathrm{P}}$ - photochemical quenching coefficient; $\mathrm{q}_{\mathrm{NP}}$ - nonphotochemical quenching coefficient.

\begin{tabular}{lllllll}
\hline Factor & $\begin{array}{l}\text { Greenness index } \\
\text { [relative unit }]\end{array}$ & $\mathrm{F}_{0}$ & $\mathrm{~F}_{\mathrm{v}} / \mathrm{F}_{\mathrm{m}}$ & $\Phi_{\mathrm{PSII}}$ & $\mathrm{q}_{\mathrm{P}}$ & $\mathrm{q}_{\mathrm{NP}}$ \\
\hline Soil & $\mathrm{ns}$ & $*$ & $\mathrm{~ns}$ & $*$ & $*$ & $*$ \\
Treatment & $\mathrm{ns}$ & $\mathrm{ns}$ & $\mathrm{ns}$ & $\mathrm{ns}$ & $\mathrm{ns}$ & $\mathrm{ns}$ \\
Soil $\times$ Treatment & $\mathrm{ns}$ & $\mathrm{ns}$ & $\mathrm{ns}$ & $\mathrm{ns}$ & $\mathrm{ns}$ & $\mathrm{ns}$ \\
Date & $* * *$ & $*$ & $\mathrm{~ns}$ & $*$ & $*$ & $*$ \\
Date $\times$ Soil & $\mathrm{ns}$ & $\mathrm{ns}$ & $\mathrm{ns}$ & $\mathrm{ns}$ & $\mathrm{ns}$ & $\mathrm{ns}$ \\
Date $\times$ Treatment & $\mathrm{ns}$ & $\mathrm{ns}$ & $\mathrm{ns}$ & $\mathrm{ns}$ & $\mathrm{ns}$ & $\mathrm{ns}$ \\
Date $\times$ Soil $\times$ Treatment & $\mathrm{ns}$ & $\mathrm{ns}$ & $\mathrm{ns}$ & $\mathrm{ns}$ & $\mathrm{ns}$ & $\mathrm{ns}$ \\
\hline
\end{tabular}




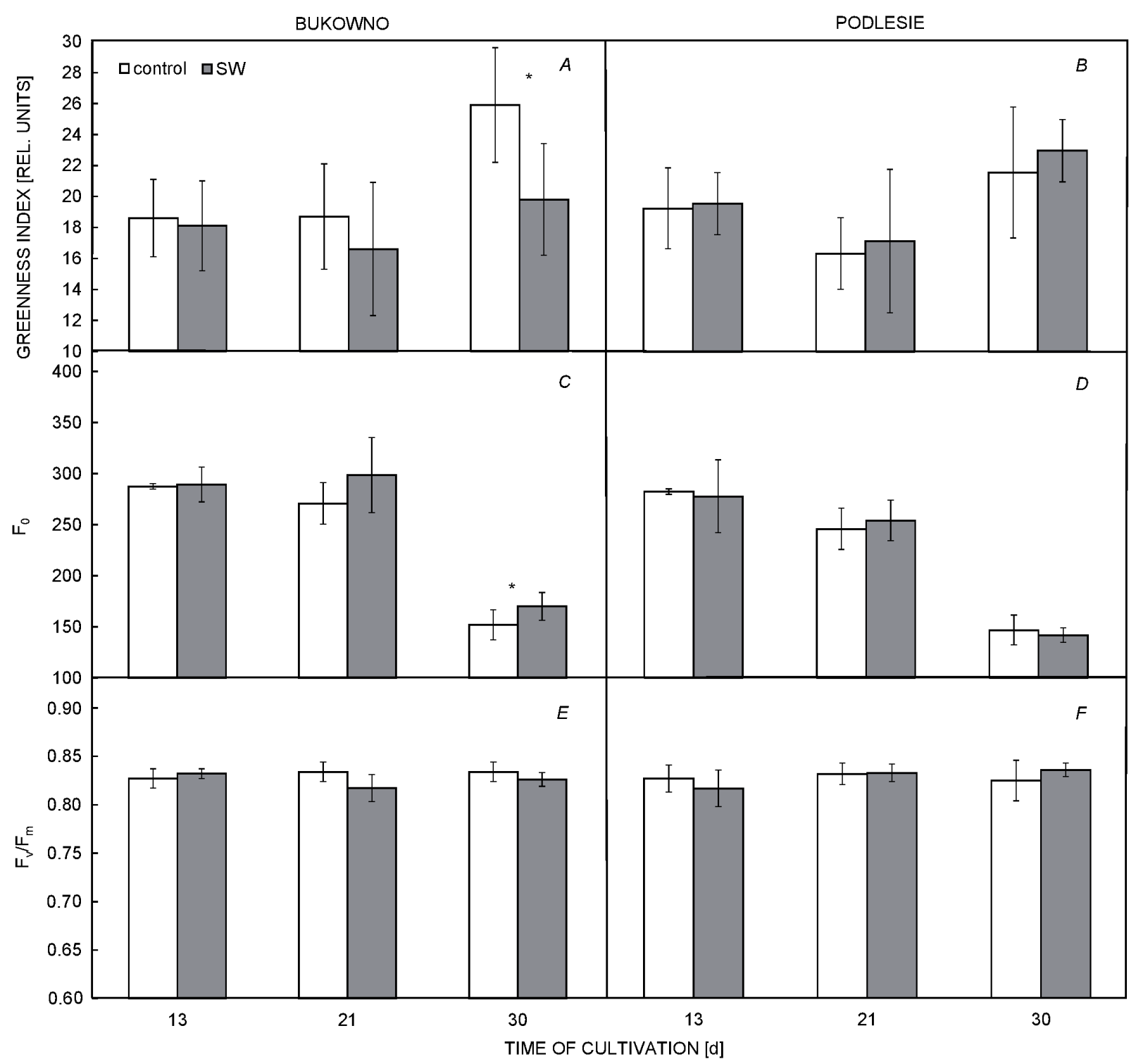

Fig. 1. Greenness index $(A, B)$ and $C F$ parameters: $\mathrm{F}_{0}(C, D)$ and $\mathrm{F}_{\mathrm{v}} / \mathrm{F}_{\mathrm{m}}(E, F)$ of cabbage seedlings grown in two soils (Bukowno contaminated with heavy metals and Podlesie poor in nutrients and acidic, see the text table in Materials and methods) and subjected to smoke water (SW). Means of $n=5 \pm \mathrm{SD}, *$ - differences significant at $p=0.05$ according to Student's $t$-test. $\mathrm{F}_{0}-$ minimal fluorescence yield of the dark-adapted state, $\mathrm{F}_{\mathrm{v}} / \mathrm{F}_{\mathrm{m}}$ - maximal quantum yield of PSII photochemistry.

Analysis of specific differences between the means related to SW (for a given measurement date) revealed that in Bukowno soil SW lowered the greenness index on $21^{\text {st }}$ day, and it was statistically significant on $30^{\text {th }}$ day (Fig. $1 A, B$ ). The drop in the greenness index was accompanied by an increase in $\mathrm{F}_{0}$ (Fig. $1 C, D$ ). $\mathrm{SW}$ used in Bukowno soil caused noticeably reduced $\Phi_{\text {PSII }}$ compared with control on $21^{\text {st }}$ and $30^{\text {rd }}$ day (Fig. $2 A$ ). In Podlesie soil, this drop was temporary (on $21^{\text {st }}$ day only, Fig. $2 B$ ). However, the pattern of changes in $\mathrm{q}_{\mathrm{P}}$ was close to that of $\Phi_{\text {PSII }}$, and the drop in qp caused by SW on $21^{\text {st }}$ day occurred in the plants in both soils (Fig. 2C,D).

Biometric parameters at the end of the experiment: ANOVA demonstrated the soil impact on five out of six considered parameters. The effects of SW treatment were also visible for five out of six parameters, although significance of both factors did not fully overlap (Table 2).

Soil type strongly affected fresh mass of the aboveground parts, and the plants of Bukowno soil had lower FM than those of Podlesie soil (Tables 2, 3). SW treatment lowered FM by $20 \%$ vs. control for both soils (no interaction, Tables 2, 3). The changes in DM of the aboveground parts and of FM of roots were similar to that of FM of the aboveground parts.

SW treatment alone did not affect DM of roots but the statistical significance of soil and soil $\times$ treatment (Table 2), visible also as a large difference between means (Table 3), indicated an inhibiting effect of the contaminants in Bukowno soil aggravated by SW.

ANOVA demonstrated the impact of soil type on plant height (Table 2). SW treatment affected both aboveground 


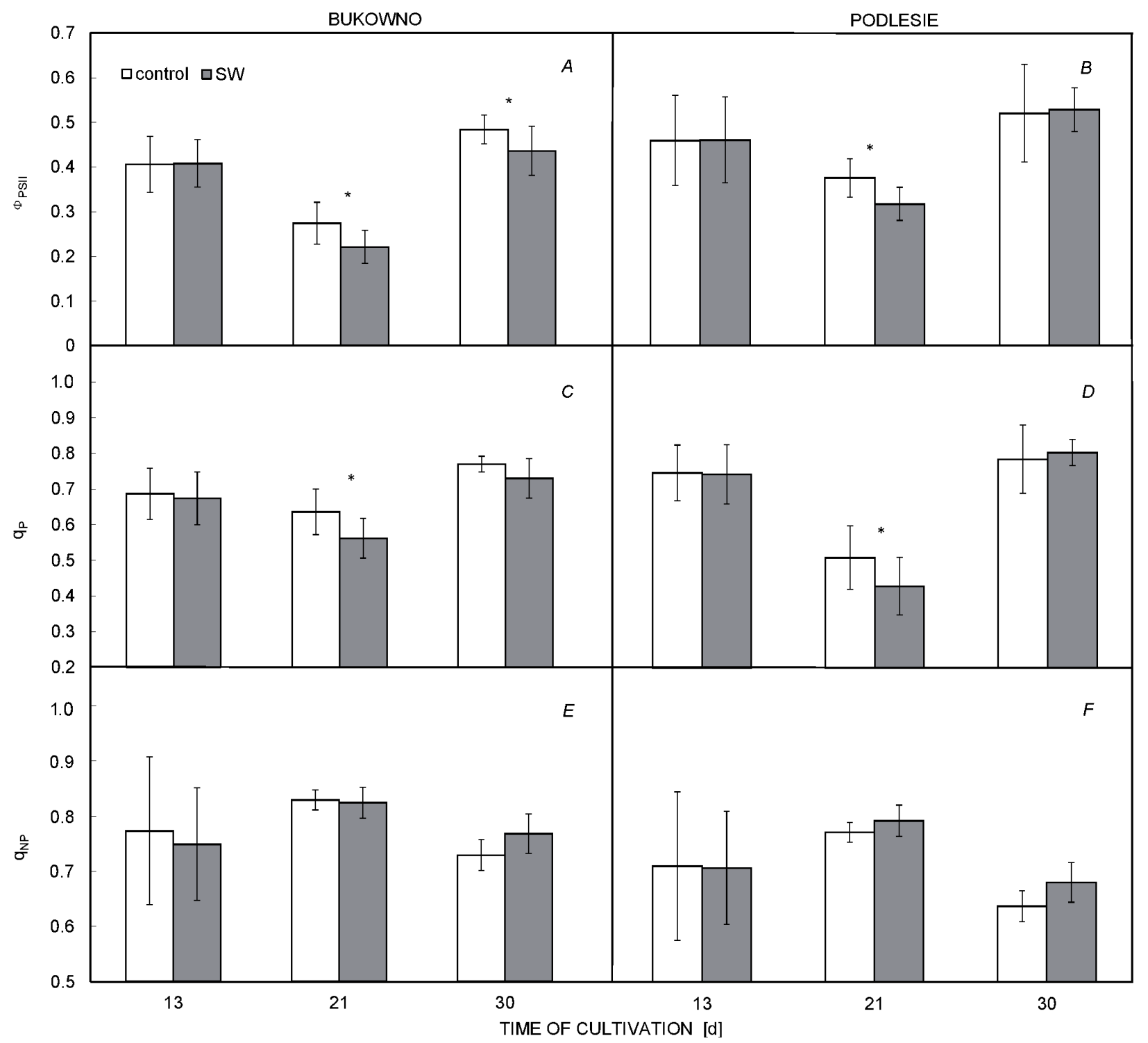

Fig. 2. CF parameters: $\Phi_{\mathrm{PSII}}(A, B), \mathrm{q}_{\mathrm{p}}(C, D)$, and $\mathrm{q}_{\mathrm{NP}}(E, F)$ of cabbage seedlings grown in two soils (Bukowno contaminated with heavy metals and Podlesie poor in nutrients and acidic, see the text table in Materials and methods) and subjected to smoke water (SW). Means of $n=5 \pm \mathrm{SD}, *$ - differences significant at $p=0.05$ according to Student's $t$-test. $\Phi_{\mathrm{PSII}}-$ effective quantum yield of PSII photochemistry, $\mathrm{q}_{\mathrm{P}}-$ photochemical quenching coefficient, $\mathrm{q}_{\mathrm{NP}}-$ nonphotochemical quenching coefficient.

Table 2. Significance of the tested factors on the biometric parameters at the end of the experiment indicating the impact of soil (Bukowno contaminated with heavy metals and Podlesie poor in nutrients and acidic, see see the text table in Materials and methods) and treatment with smoke water. $A N O V A,{ }^{* *} \alpha \leq 0.001 ; * * \alpha \leq 0.01 ; * \alpha \leq 0.05$; ns - insignificant.

\begin{tabular}{lllllll}
\hline Factor & \multicolumn{3}{l}{ Aboveground part } & \multicolumn{2}{l}{ Roots } \\
& FM $[\mathrm{g}]$ & DM $[\mathrm{g}]$ & Length $[\mathrm{cm}]$ & FM $[\mathrm{g}]$ & DM $[\mathrm{g}]$ & Length $[\mathrm{cm}]$ \\
\hline Soil & $* * *$ & $* *$ & $* *$ & $*$ & $* *$ & $\mathrm{~ns}$ \\
Treatment & $* * *$ & $*$ & $* *$ & $*$ & $\mathrm{~ns}$ & $* *$ \\
Soil $\times$ Treatment & $\mathrm{ns}$ & $\mathrm{ns}$ & $* *$ & $\mathrm{~ns}$ & $*$ & $* *$ \\
\hline
\end{tabular}

parts and roots, and significance of interaction between treatments was also established (Table 2). SW diminished plant height in Podlesie soil but the length of their roots increased to $150 \%$ of control (Table 3 ). The aboveground parts and roots of Bukowno plants were as long as the control ones (Table 3). 
Table 3. Biometric parameters of cabbage seedlings on $40^{\text {th }}$ day of cultivation in two soils, Bukowno contaminated with heavy metals and Podlesie poor in nutrients and acidic (see the text table in Materials and methods). Means of $n=5 \pm \mathrm{SD}$. Different letters indicate statistically significant differences between means within the soil (Student's $t$-test; $p<0.05$ ). FM - fresh mass; DM - dry mass, $\mathrm{SW}$ - smoked water.

\begin{tabular}{lllllll}
\hline Soil and treatment & \multicolumn{5}{l}{ Aboveground part } & Roots \\
& FM [g] & DM $[\mathrm{g}]$ & Length [cm] & FM [g] & DM [g] & Length [cm] \\
\hline \multirow{2}{*}{ Bukowno, control } & $5.64 \pm 0.88^{\mathrm{a}}$ & $0.86 \pm 0.18^{\mathrm{a}}$ & $6.68 \pm 0.50^{\mathrm{a}}$ & $24.1 \pm 2.05^{\mathrm{a}}$ & $5.64 \pm 0.62^{\mathrm{a}}$ & $16.5 \pm 1.42^{\mathrm{a}}$ \\
& $100 \%$ & $100 \%$ & $100 \%$ & $100 \%$ & $100 \%$ & $100 \%$ \\
Bukowno, SW & $4.55 \pm 0.61^{\mathrm{b}}$ & $0.69 \pm 0.13^{\mathrm{b}}$ & $6.64 \pm 0.35^{\mathrm{a}}$ & $18.9 \pm 2.80^{\mathrm{b}}$ & $3.84 \pm 0.60^{\mathrm{b}}$ & $17.3 \pm 3.47^{\mathrm{a}}$ \\
& $81 \%$ & $80 \%$ & $99 \%$ & $78 \%$ & $68 \%$ & $107 \%$ \\
Podlesie, control & $7.87 \pm 0.97^{\mathrm{a}}$ & $0.98 \pm 0.15^{\mathrm{a}}$ & $8.50 \pm 1.02^{\mathrm{a}}$ & $28.5 \pm 7.87^{\mathrm{a}}$ & $6.40 \pm 2.18^{\mathrm{a}}$ & $12.0 \pm 1.93^{\mathrm{b}}$ \\
& $100 \%$ & $100 \%$ & $100 \%$ & $100 \%$ & $100 \%$ & $100 \%$ \\
Podlesie, SW & $6.52 \pm 0.98^{\mathrm{b}} \%$ & $0.88 \pm 0.13^{\mathrm{b}}$ & $6.98 \pm 0.80^{\mathrm{b}}$ & $25.4 \pm 7.87^{\mathrm{b}}$ & $6.63 \pm 1.13^{\mathrm{a}}$ & $18.4 \pm 7.25^{\mathrm{a}}$ \\
& $83 \%$ & $92 \%$ & $82 \%$ & $89 \%$ & 104 & $150 \%$ \\
\hline
\end{tabular}

\section{Discussion}

The soil used in the experiment came from Bukowno area harboring Mining and Metallurgy Enterprise ZGH Bolesław that processes zinc and lead ore. The soil features markedly higher contents of heavy metals than that of regular arable soil (Kabata-Pendias and Mukherjee 2007). Studies on vegetation around ZGH Bolesław indicated a negative impact of anthropogenic pollution (Kapusta et al. 2015, Zielonka et al. 2015), and our study confirmed this finding.

Four out of five CF parameters changed in our experiment $-\mathrm{F}_{0}$ and $\mathrm{q}_{\mathrm{NP}}$ rose, and $\Phi_{\mathrm{PSII}}$ and $\mathrm{q}_{\mathrm{P}}$ declined in Bukowno plants. These alterations suggested damage to plant photosynthetic apparatus. Higher $\mathrm{F}_{0}$ may indicate dissociation of the antennae (LHCII) from PSII, inhibition of the acceptor side of PSII, or reduction of quinone A (Yamane et al. 2000, Bertamini and Nedunchezhian 2003). Greenness index often inversely correlates with $F_{0}$, i.e. the higher the greenness index, the lower $\mathrm{F}_{0}$ values. Other papers demonstrating elevated $\mathrm{F}_{0}$ accompanying a decrease in Chl pool seem to confirm this claim (Baker et al. 2008, Borek et al. 2016). Moreover, lowered $\Phi_{\text {PSII }}$ and $\mathrm{q}_{\mathrm{P}}$ values in the plants in Bukowno soil indicate that a small portion of the light absorbed by the Chls of the PSII antenna is converted into photochemical energy and $\mathrm{CO}_{2}$ processing (Kalaji et al. 2014). Additionally, higher $\mathrm{q}_{\mathrm{NP}}$ reflects increased dissipation of absorbed light energy (Maxwell and Johnson 2000, Sofo et al. 2009). Negative impact of the soil on the seedlings was also reflected in their fresh and dry mass that were lower for Bukowno than that of Podlesie soil. Hence, the plants suffered more from metallic contaminants in Bukowno soil than from acidity and lack of nutrients in sandy soil from Podlesie.

The correlation between the greenness index and measurement date means its temporary drop was irrespective of the soil conditions. In other words, these changes indicated acclimation of seedlings to both soils. The values of the greenness index in the plants growing in Bukowno soil on the last measurement date $\left(30^{\text {rd }}\right.$ day) increased considerably in both control and SW plants vs. $21^{\text {st }}$ day. Moreover, normalization of most of CF parameters after the drop on $21^{\text {st }}$ day indicated a gradual adaptation of plants. We could expect the seedlings to intensify the uptake of nutrients and their use. However, this did not correlate with biomass growth. Probably not only the photosynthetic productivity but also distribution of assimilates under these conditions focused on reinforcing the protective mechanisms against toxic effects of heavy metals (Gajewska et al. 2013).

$\mathrm{F}_{\mathrm{v}} / \mathrm{F}_{\mathrm{m}}$, often used as an indicator of the photosynthetic apparatus damage (Demmig and Björkmann 1987), is insensitive to the experimental factors. Numerous authors have already mentioned that $\mathrm{F}_{\mathrm{v}} / \mathrm{F}_{\mathrm{m}}$ should not be used as a sole CF parameter depicting plant fitness (Bączek-Kwinta et al. 2011a, Borek et al. 2016, Peng et al. 2017), and our study confirms this recommendation.

Physiological mode of action of the SW components should be explained. Smoke compounds, mostly karrikins and trimethylbutenolide, interact with some phytohormones, which means plant response is highly complex (Thomas and Van Staden 1995, Nelson et al. 2009, Meng et al. 2016). Moreover, karrikins may also affect respiratory processes and deplete the pool of metabolic energy (Chen et al. 2016).

In our experiment, we only applied SW once and at a low concentration. Dry litter/water ratio was 1:30 and the stock was diluted 1:1,000. Kulkarni et al. (2008) prepared the stock SW using dry litter/water ratio 1:10, then diluted it 1:500 and 1:2,000 (v/v). Zuloaga-Aguilar et al. (2011) prepared the 1:10 stock and used it without dilution. Complex ways, in which karrikins and other smoke compounds change plant physiology, may explain why in our experiment the effects of SW on CF parameters were sometimes insignificant but appeared especially when the plants suffered from the heavy metals ( $21^{\text {st }}$ day). Individual differences between control and SW were transient $\left(\mathrm{q}_{\mathrm{P}}\right)$, noticeable on the last measurement date (greenness index, $\left.\mathrm{F}_{0}\right)$, or both ( $\Phi_{\mathrm{PSII}}$ for Bukowno).

The impact of SW was more conspicuous in Bukowno soil, and the alterations in some biometric parameters identified smoke water as an additional plant stressor. Plants grown in different soils responded differently to SW in terms of root/shoot ratio. Seedlings cultivated in Podlesie soil produced noticeably longer roots when treated with SW. This may be explained directly by the 
soil composition and $\mathrm{pH}$ or indirectly by the presence of a different microbiota (Mandabi et al. 2014, Flematti et al. 2015), which suggests the direction of further research on the impact of SW on soil microorganisms.

Conclusions: The experiment involved two agricultural soils - one contaminated with heavy metals and another sandy and poor in nutrients. Single application of aqueous smoke solution (SW) aggravated the negative impact of contaminants on cabbage seedlings grown in these soils. The affected traits included photosynthetic performance and plant growth and development. Although SW may be used as plant biostimulant with a known mode of action, it is not recommended for cabbage plants used as phytoremediators. Moreover, as burning of grasses (swailing) may increase concentration of smoke compounds in the soil, accidental or illegal swailing in the vicinity of crops grown on metal-contaminated or poor acidic soils may negatively affect the plants.

\section{References}

Baker N.R.: Chlorophyll fluorescence: a probe of photosynthesis in vivo. - Annu. Rev. Plant Biol. 59: 89-113, 2008.

Bączek-Kwinta R.: Swailing affects seed germination of plants of European bio-and agricenosis in a different way. - Open Life Sci. 12: 62-75, 2017.

Bączek-Kwinta R., Kozieł A., Seidler-Łożykowska K.: Are the fluorescence parameters of German chamomile leaves the first indicators of the anthodia yield in drought conditions? Photosynthetica 49: 87-97, 2011 a.

Bączek-Kwinta R., Bartoszek A., Kusznierewicz B., Antonkiewicz J.: Physiological response of plants and cadmium accumulation in heads of two cultivars of white cabbage. $-\mathrm{J}$. Elementol. 16: 355-364, 2011b.

Bertamini M., Nedunchezhian N.: Photoinhibition of photosynthesis in mature and young leaves of grapevine (Vitis vinifera L.). - Plant Sci. 164: 635-644, 2003.

Borek M., Bączek-Kwinta R., Rapacz M.: Photosynthetic activity of variegated leaves of Coleus $x$ hybridus Hort. cultivars characterised by chlorophyll fluorescence techniques. Photosynthetica 54: 331-339, 2016.

Cassol D., De Silva F.S.P., Falqueto A.R., Bacarin M.A.: An evaluation of non-destructive methods to estimate total chlorophyll content. - Photosynthetica 46: 634-636, 2008.

Chen C., Wu Q., Shan L. et al.: Discovery of cytochrome $\mathrm{bc}_{1}$ complex inhibitors inspired by the natural product karrikinolide. - RSC Adv. 6: 97580-97586, 2016.

Cosgrove P.: Cairngorms National Park. The Burning Issue: A Briefing Paper on Fire and the Natural Heritage. CNPA Briefing Paper No. 3. Pp. 1-11. Cairngorms National Park. National Resources Group, 2004

Dayamba S.D., Sawadogo L., Tigabu M. et al.: Effects of aqueous smoke solutions and heat on seed germination of herbaceous species of the Sudanian savanna-woodland in Burkina Faso. Flora 205: 319-325, 2010.

Demmig B., Björkman O.: Comparison of the effect of excessive light on chlorophyll fluorescence $(77 \mathrm{~K})$ and hoton yield of $\mathrm{O}_{2}$ evolution in leaves of higher plants. - Planta 171: 171-184, 1987.

Egner H., Riehm H., Domingo W.R.: [Studies on soil chemical analysis as a basis for the assessment of nutrient levels of soil. II. Chemical extraction methods for phosphorus and potassium determination.] - Landbrukshoegsk. Anniv. 26:
204-209, 1960. [In German]

Flematti G.R., Waters M.T., Scaffidi A. et al.: Karrikin and cyanohydrin smoke signals provide clues to new endogenous plant signaling compounds. - Molec. Plant 6: 29-37, 2013.

Flematti G.R., Dixon K.W, Kingsley S.M.: What are karrikins and how were they 'discovered' by plants? - BMC Biology 13: 108, 2015.

Gajewska E., Niewiadomska E., Tokarz K. et al.: Nickel-induced changes in carbon metabolism in wheat shoots. - J. Plant Physiol. 170: 369-377, 2013.

Genty B., Briantais J.M., Baker N.M.: The relationship between the quantum yield of photosynthetic electron transport and quenching of chlorophyll fluorescence. - Biochim. Biophys. Acta 990: 87-92, 1989.

Gruszecka-Kosowska A., Kicińska A.: Long-term metal-content changes in soils on the Olkusz $\mathrm{Zn}-\mathrm{Pb}$ Ore-bearing area, Poland. - Int. J. Environ. Res. 11: 359-376, 2017.

Jones J.B. Jr., Case V.V.: Sampling, handling, and analyzing plant tissue samples. - In: Westerman R.L. (ed.): Soil Testing and Plant Analysis, Ed 2. SSSA Book Series, No. 3. Pp. 389-427. Soil Science Society of America, Madison 1990.

Kabata-Pendias A., Mukherjee A.B.: Trace Elements from Soil to Human. Pp. 87-93. Springer-Verlag, Berlin - Heidelberg 2007.

Kabata-Pendias A., Piotrowska M., Motowicka-Terelak T. et al.: Basis for the Assessment of Chemical Contamination of Soil - Heavy Metals, Sulfur and PAHs. Pp. 41. State Inspectorate for Environmental Protection. Library of Environmental Monitoring, Warsaw 1995.

Kalaji H.M., Schansker G., Ladle R.J. et al.: Frequently asked questions about in vivo chlorophyll fluorescence: practical issues. - Photosynth Res. 122: 121-158, 2014.

Kapusta P., Szarek-Łukaszewska G., Vogt R.D.: Physicochemical and biological properties of soils in the prevailing types in the communities in the Olkusz mining region. - In: Godzik B. (ed.): Natural and Historical Values of the Olkusz Ore-bearing Region. Pp. 269-283. Władysław Szafer Institute of Botany, PAS, Kraków 2015.

Kochanek J., Long R.L., Lisle A.T., Flematti G.R.: Karrikins identified in biochars indicate post-fire chemical cues can influence community diversity and plant development. PLoS ONE 11: e0161234, 2016.

Kulkarni M.G., Ascough G.D., Van Staden J.: Smoke-water and a smoke-isolated butenolide improve growth and yield of tomatoes under greenhouse conditions. - Hort. Technol. 18: 449-454, 2008.

Kulkarni M.G., Light M.E., Van Staden J.: Plant-derived smoke: Old technology with possibilities for economic applications in agriculture and horticulture. - South Afr. J. Bot. 77: 972979, 2011.

Kusznierewicz B., Bączek-Kwinta R., Bartoszek A. et al.: The dose-dependent influence of zinc and cadmium contamination of soil on their uptake and glucosinolate content in white cabbage (Brassica oleracea var. capitata $\mathrm{f}$. alba). - Environ. Toxicol. Chem. 31: 2482-2489, 2012.

Long R., Stevens J.C., Griffiths E.M. et al.: Detecting karrikinolide responses in seeds of the Poaceae. - Aust. J. Bot. 59: 609-619, 2011.

Łukowiak R., Grzebisz W., Sassenrath G.F.: New insights into phosphorus management in agriculture - A crop rotation approach. - Sci. Total Environ., 542: 1062-1077, 2016.

Mandabi A., Ganin H., Krief P. et al.: Karrikins from plant smoke modulate bacterial quorum sensing, - Chem. Commun. 50: 5322-5325, 2014.

Marcinek J., Komisarek J. (ed.): [Polish Soil Classification.] Soil Sci. Annu. 62: 1-193, 2011. [In Polish] 
Maxwell K., Johnson G.N.: Chlorophyll fluorescence - a practical guide. - J. Exp. Bot. 51: 659-668, 2000.

Meng Y., Chen F., Shuai H. et al.: Karrikins delay soybean seed germination by mediating abscisic acid and gibberellin biogenesis under shaded conditions. - Sci. Rep. 6: 22073, 2016.

Murchie E.H., Lawson T.: Chlorophyll fluorescence analysis: a guide to good practice and understanding some new applications. - J. Exp. Bot. 64: 3983-3998, 2013.

Nelson D.C., Riseborough J.-A., Flematti G.R. et al.: Karrikins discovered in smoke trigger Arabidopsis seed germination by a mechanism requiring gibberellic acid synthesis and light. Plant Physiol. 149: 863-873, 2009.

Ostrowska A., Gawliński S., Szczubiałka Z.: Methods of Analysis and Assessment of Soil and Plant Properties. A Catalogue. Pp. 334. Institute of Environmental Protection - National Research Institute, Warsaw 1991.

Peng J.G., Jiang X.R., Xu J. et al.: Underestimated chlorophyll a fluorescence measurements on Buxus microphylla red winter leaves. - Photosynthetica 55: 561-567, 2017

Pošta M., Light M.E., Papenfus H.B. et al.: Structure-activity relationships of analogs of 3,4,5-trimethylfuran-2 $(5 \mathrm{H})$-one with germination inhibitory activities. - J. Plant Physiol. 170: 1235-1242, 2013.

Pošta M., Papenfus H.B., Light M.E. et al.: Structure-activity relationships of $N$ - and $S$-analogs of the seed germination inhibitor (3,4,5-trimethylfuran-2(5H)-one) for mode of action elucidation. - Plant Growth Regul. 82: 47-53, 2017.

Reyes O., Trabaud Ć.L.: Germination behaviour of 14 Mediterranean species in relation to fire factors: smoke and heat. - Plant
Ecol. 202: 113-121, 2009.

Schreiber U., Schliwa U., Bilger W.: Continuous recording of photochemical and non-photochemical chlorophyll fluorescence with a new type of modulation fluorometer. Photosynth. Res. 10: 51-62, 1986.

Sofo A., Dichio B., Montanaro G., Xiloyannis C.: Photosynthetic performance and light response of two olive cultivars under different water and light regimes. - Photosynthetica 47: 602608,2009

Thomas T.H., van Staden J.: Dormancy break of celery (Apium graveolens L.) seeds by plant derived smoke extract. - Plant Growth Regul. 17: 195-198, 1995.

van de Wiel H.J.: Determination of elements by ICP-AES and ICP-MS. National Institute of Public Health and the Environment (RIVM), Bilthoven, The Netherlands. https:// www.ecn.nl/docs/society/horizontal/hor_desk_19_icp.pdf.

Yamane Y., Shikanai T., Kashino Y. et al.: Reduction of $\mathrm{Q}_{\mathrm{A}}$ in the dark: another cause of fluorescence $\mathrm{F}_{0}$ increases by high temperatures in higher plants. - Photosynth. Res. 63: 23-34, 2000.

Zielonka T., Dubaj N., Malcher P.: Growth dynamics in scots pine (Pinus sylvestris) in the Olkusz Ore-bearing region. - In: Godzik B. (ed.): [Natural and Historical Values of the Olkusz Ore-bearing Region.] Pp. 259-265. Władysław Szafer Institute of Botany, PAS, Kraków 2015.

Zuloaga-Aguilar S., Briones O., Orozco-Segovia A.: Seed germination of montane forest species in response to ash, smoke and heat shock in Mexico. - Acta Oecol. 37: 256-262, 2011.

(C) The authors. This is an open access article distributed under the terms of the Creative Commons BY-NC-ND Licence. 